\title{
Ion activity products of iron sulfides in groundwaters: Implications from the Choshui fan-delta, Western Taiwan
}

\author{
Wen-Fu Chen ${ }^{*} \dagger$ and Tsung-Kwei Liu \\ Department of Geosciences, National Taiwan University, Taiwan
}

(Received August 17, 2004; accepted in revised form March 2, 2005)

\begin{abstract}
Precipitation of iron sulfides is an important process in groundwater geochemistry because it reduces iron mobility in anaerobic aquifers. Iron sulfides occur in various allotropic forms such as amorphous $\mathrm{FeS}$ and pyrite, and their solubility products differ up to 13 orders of magnitude. However, few data for ion activity products (IAP) of iron sulfides defined by the equation: $\mathrm{H}^{+}+\mathrm{FeS}_{(\mathrm{S})}=\mathrm{Fe}^{2+}+\mathrm{HS}^{-}$in groundwater have been reported in the literature. We computed IAP values of iron sulfides for 46 groundwater samples from the Choshui fan-delta of Taiwan and 65 samples from other areas of the world. The mean of - $\log$ (IAP) values obtained for the 46 samples is $3.07 \pm 0.34(1 \sigma)$, which is consistent with the solubility constant 3.00 \pm 0.12 (Davison et al., 1999) of amorphous FeS, implying that the anaerobic aquifers in the Choshui fan-delta are still undergoing active sulfate-reduction processes and keeping the groundwater saturated with amorphous FeS.

We suggest that the $-\operatorname{logKsp}$ value 3.91 of amorphous FeS adopted in the databases for WATEQF and PHREEQC computer programs ought to be revised to 3.00. Otherwise, the saturation indices (SI) calculated by the two computer programs will be an order of magnitude too high. Copyright @ 2005 Elsevier Ltd
\end{abstract}

\section{INTRODUCTION}

Groundwater with high concentration of dissolved iron tends to cause yellow stains and pipe encrustation once subjected to higher oxidation condition. On the other hand, sulfate-reducing processes can decrease iron mobility in anaerobic aquifers by causing precipitation of iron sulfide minerals. Thus iron sulfide geochemistry is an important characteristic in evaluating and exploiting groundwater resources.

Iron sulfides commonly occur as various allotropic forms, such as mackinawite $(\mathrm{FeS})$, greigite $\left(\mathrm{Fe}_{3} \mathrm{~S}_{4}\right)$ and amorphous $\mathrm{FeS}$, all of which are meta-stable and classified as acid volatile sulfides (AVS), as well as stable pyrite $\left(\mathrm{FeS}_{2}\right)$ (Morse et al., 1987). Solubility product of iron sulfides is defined by the equation: $\mathrm{H}^{+}+\mathrm{FeS}_{(\mathrm{S})}=\mathrm{Fe}^{2+}+\mathrm{HS}^{-}$. The negative logarithms of the solubility constant, i.e., $-\log \mathrm{K}$, of amorphous FeS, mackinawite, greigite, and pyrite are 3.00 (Davison et al., 1999), 3.55, 12.85, and 16.40, respectively (Berner, 1967; Douabul and Riley, 1979; Morse et al., 1987). Experiments demonstrated that in the presence of dissolved sulfide species, ferrous iron precipitates as amorphous $\mathrm{FeS}$ within seconds (Rickard, 1989). In contrast, mackinawite, greigite and pyrite take hours to hundred days to precipitate (Berner, 1967, 1970; Sweeney and Kaplan, 1973; Wilkin and Barnes, 1996, 1997; Benning et al., 2000).

Pyrite is expected to be the only iron sulfide species in deep $(>150 \mathrm{~m})$ confined aquifers beneath the Choshui fan-delta, which has estimated groundwater flow velocities of $<10 \mathrm{~m} / \mathrm{yr}$ (Liu, 1995; Chen and Liu, 2003). The solubility of pyrite is 13 orders of magnitude lower than amorphous FeS (Morse et al.,

\footnotetext{
* Author to whom correspondence should be addressed (chenwenfu@ntu.edu.tw).

${ }^{\dagger}$ Present address: 60 Erh-Jen Rd., Sec. 1, Pao-An, Jen-Te, Tainan County 717, Taiwan. Taiwan Hot Spring Research Center, Chia-Nan University of Pharmacy and Science.
}

1987). However, few studies have been conducted on the ion-activity products (IAP) of iron sulfide species in groundwater (Davison, 1980). The purpose of this paper is to present groundwater IAP data for iron sulfides from 191 monitoring wells in the Choshui fan-delta, western Taiwan and to investigate whether the groundwater is saturated with respect to iron sulfides. In addition, we compare ion activity products of iron sulfides in anaerobic groundwater environments from available publications with our results.

\section{HYDROGEOLOGY}

The Choshui fan-delta, ca. $40 \mathrm{~km}$ long from its topographic apex to the coast and $60 \mathrm{~km}$ wide along the coast, is composed of sediments mainly transported by the Choshui River (Chen and Liu, 2003; Fig. 1A). Its topographic surface extends smoothly from an altitude of ca. $100 \mathrm{~m}$ on the east down to sea level on the west. From east to west, a thick unconsolidated gravel layer gradually changes to sands and clays. The uppermost $60 \mathrm{~m}$ thick layer of sediments was deposited during the Holocene (e.g., in well HA of Fig. $1 \mathrm{~B},{ }^{14} \mathrm{C}$ age $=8140 \pm 85$ B.P. at $45 \mathrm{~m}$ depth), which in turn is underlain disconformably by late Pleistocence strata $\left({ }^{14} \mathrm{C}\right.$ age $=24050 \pm 280$ B.P. at $62 \mathrm{~m}$ depth) (Fig. 1B; CGS, 1995).

The thick $(>250 \mathrm{~m})$ gravel-dominated aquifer that occupies the eastern part of the fan-delta is unconfined in hydrogeological character (AF1 in Fig. 1B). A regional silty-clayey aquitard (named as Huchi aquitard; Liu, 1995) occurs at the depth interval of 30-60 m (between AF1 and AF2 in Fig. 1B) in the middle and distal parts of the fan-delta. The three confined aquifers below the Huchi aquitard (AF2, AF3 and AF4 in Fig. 1B) are separated by two aquitards (each is $10-20 \mathrm{~m}$ in thickness) at depths of ca. 105 and $200 \mathrm{~m}$, respectively.

A total of 191 monitoring wells at 85 different sites (Fig. 1A) were drilled during the period from 1991 to 1997 . The average distance between two neighboring sites is $6 \mathrm{~km}$. The deepest 

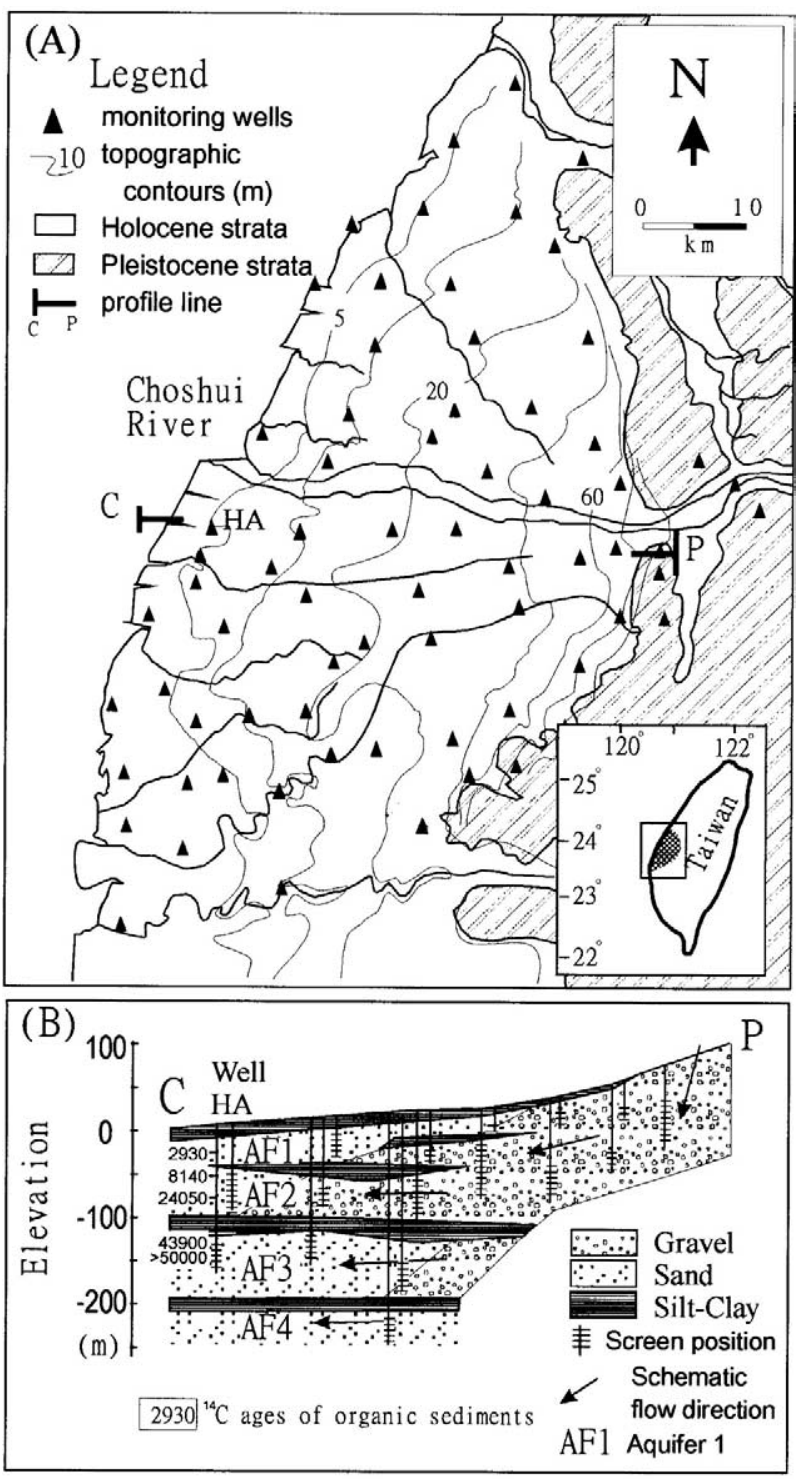

Fig. 1. (A) Locations of the monitoring wells and topography of the Choshui fan-delta, Taiwan. (B) A hydrogeological profile along line C-P in (A).

well is $\sim 300 \mathrm{~m}$. Bentonite was used to seal each aquifer and avoid mixing water from the upper and lower aquifers.

Groundwater in the fan-delta flows seaward in a pattern similar to the direction of surface water flow (WRA, 2000; Liu, 1995). The proximal part serves as the main recharge area for the confined aquifers in the down-gradient parts towards the west. All groundwater samples from this recharge area have tritium concentration $>1 \mathrm{TU}$ (Liu, 1995) and are considered to include recharge that entered after the commencement of frequent atomic bomb tests during the decade of 1953 to 1963.

\section{ANALYTICAL METHODS}

Water samples were collected during the period from November 1998 to April 1999. The field sampling methods used follow the NIEA code W103.50B set by Taiwan Environment Protection Agency (http:// www.niea.gov.tw/). As least three volumes of stagnant water within the casing of each well were pumped before sampling. Dissolved oxygen (DO), temperature, $\mathrm{pH}$, electrical conductivity (EC), Eh (redox potential), and turbidity were measured in a flow-through cell every $5 \mathrm{~min}$ during well purging. Cell sensors were calibrated with standard solutions (all from Merck), which have $\mathrm{pH}=4.00,7.00$ and 10.0; EC $=1410 \mu \mathrm{S} / \mathrm{cm} ; \mathrm{Eh}=+280 \mathrm{mV}$, in the field before measuring any of these parameters (APHA, 1998). Water samples were collected only after $\mathrm{pH}$ and $\mathrm{EC}$ stabilized, and the fluctuations of $\mathrm{pH}$ and relative EC were less than 0.1 and $5 \%$, respectively.

After purging, a probe (MiniSonde manufractured by HydroLab, USA), which is $5 \mathrm{~cm}$ in diameter and $70 \mathrm{~cm}$ in length, including a data logger, a circulator and five sensors for temperature, $\mathrm{EC}, \mathrm{pH}$, Eh and DO measurements, was lowered down to the screen position of the well casing and remained there for at least $10 \mathrm{~min}$ before water quality parameters were read (Chen and Liu, 2003). The $\mathrm{pH}$ values read from the downhole probe were used to calculate the ion activity products of iron sulfides.

Water samples for metal and other cation concentration measurements were filtered with $0.45 \mu \mathrm{m}$ glass fiber papers and acidified with nitric acid (Merck ultrapure grade) to $\mathrm{pH}$ 2. Samples for sulfide analyses were collected in narrow-mouth biochemical oxygen demand (BOD) bottles $(300 \mathrm{~mL})$ with tapered ground-glass stoppers and flared mouths. To avoid trapping or dissolving atmospheric oxygen, a rubber tube was extended from the pump line to the bottom of the bottle. After two or three bottle volumes of water flowed out, a stopper was placed tightly without air bubbles. Samples were then kept in ice boxes and delivered to the laboratory within 24 hours.

Water for total dissolved solids (TDS) determination was dried at 103 to $105^{\circ} \mathrm{C}$. Dissolved organic carbon (DOC) was measured using the high temperature combustion method (APHA, 1998). Anions of $\mathrm{NO}_{3}{ }^{-}, \mathrm{SO}_{4}{ }^{2-}$ and sulfide were determined by spectrophotometric techniques using the cadmium reduction, turbidimetric, and methylene blue methods, respectively (APHA, 1998). Trace metal ions including iron were measured by atomic absorption spectroscopy (AAS).

A total of 15 samples including blank, spike, duplicate and check samples (standard solutions from Merck) were measured sequentially (APHA, 1998). For sulfides, the lower detection limit was $0.03 \mathrm{mg} / \mathrm{L}$; variances of duplicate measurements were less than $10 \%$; recoveries of check and spike samples were between 85 and $115 \%$. For iron, the lower detection limit was $0.05 \mathrm{mg} / \mathrm{L}$; variances of duplicate measurements were less than $3 \%$; recoveries of check and spike samples were between 90 and $110 \%$.

\section{ION ACTIVITY PRODUCTS OF SULFIDE-DETECTABLE GROUNDWATERS}

Of the total 191 groundwater samples collected, 27 samples (14\% of all the samples) were aerobic with dissolved oxygen or nitrate- $\mathrm{N}$ contents greater than $0.5 \mathrm{mg} / \mathrm{L}$ (Appendix 1). The other 164 samples had Eh values between 0 and $-300 \mathrm{mV}$ and are considered to be anaerobic. A total of 118 of the anaerobic samples contained sulfide concentration below the detection limit (i.e., $<0.03 \mathrm{mg} / \mathrm{L}$ ), whereas 46 samples contained detectable sulfide. These sulfide-detectable samples had $\mathrm{pH}$ values ranging from 7.5 to $8.5, \mathrm{Fe}^{+2}$ concentrations from 0.1 to 10 $\mathrm{mg} / \mathrm{L}$, and TDS values lower than $1000 \mathrm{mg} / \mathrm{L}$ (Fig. 2).

Ion activity products for iron sulfides were calculated by the equation

$$
\mathrm{IAP}=\frac{\left\{\mathrm{Fe}^{2+}\right\}\left\{\mathrm{HS}^{-}\right\}}{\left\{\mathrm{H}^{+}\right\}}
$$

The symbols \{\} denote activities. The values of ionic activity were calculated from the Debye-Huckel equation at the ionic strength (I), where I $=2.5 \times 10^{-5} \times$ TDS (in mg/L) (Langelier, 1936; Hem, 1992). The $\mathrm{Fe}^{2+}$ used in the calculation was assumed to be the measured iron concentration. The concentration of sulfide from methylene blue measurements is the sum 

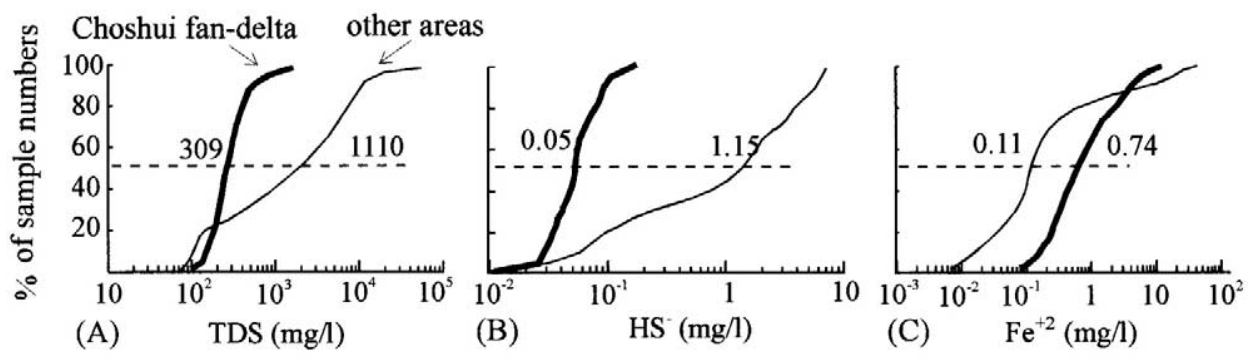

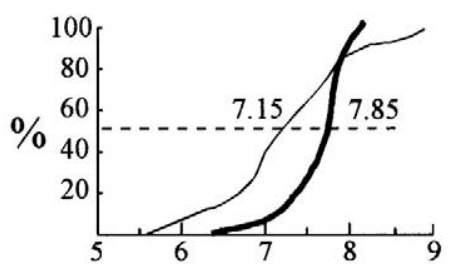

(D)

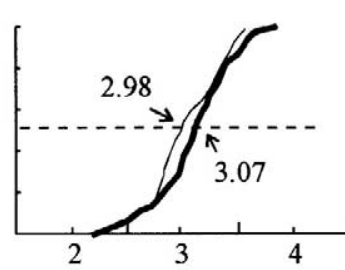

(E)

$-\log (\mathrm{IAP})$

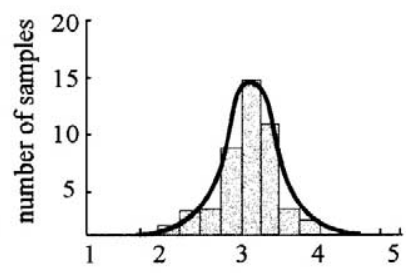

(F) $\quad-\log (\mathrm{IAP})$

Fig. 2. (A) to (D) Cumulative curves of total dissolved solid (TDS), dissolved sulfide ( $\left.\mathrm{HS}^{-}\right)$, iron $\left(\mathrm{Fe}^{+2}\right)$ and $\mathrm{pH}$ for two data groups. Heavy lines represent the group of 46 groundwater samples from Choshui fan-delta aquifers, Taiwan; light lines represent the group of the 65 samples collected from other anaerobic aquifers. TDS, $\mathrm{pH}, \mathrm{HS}^{-}$and iron concentrations of the two data groups are remarkably different. (E) The median value of $-\log (\mathrm{IAP})$ from Choshui fan-delta is 3.07 and $80 \%$ of the values fall between 2.68 to 3.49. Of the total 65 samples from other aquifers, $75 \%$ samples have the $-\log (\mathrm{IAP})$ values less than mackinawite's pKsp 3.55 and with a median value of 2.98. (F) A histogram of $-\log (\mathrm{IAP})$ values for the 46 samples from Choshui fan-delta showing a normal distribution with a mean value of $3.07 \pm 0.34(1 \sigma)$.

of $\mathrm{H}_{2} \mathrm{~S}, \mathrm{HS}^{-}$and $\mathrm{S}^{-2}$. Concentrations of $\mathrm{HS}^{-}$are calculated by assuming the first and second acidity constants of $\mathrm{H}_{2} \mathrm{~S}$ as $\mathrm{pK}_{1}$ $=7$ and $\mathrm{pK}_{2}=14$ (Stumm and Morgan, 1995, p.398). The IAPs, represented as $-\log (\mathrm{IAP})$, for the 46 samples with detectable sulfide concentration range from 2.20 to 3.83 . The median value of $-\log ($ IAP) is 3.07 and $80 \%$ of the values fall between 2.68 to 3.49 (Fig. 2E).

A reliable measurement of the solubility product for amorphous FeS made by Berner (1967) was $2.95 \pm 0.1$ at $\mathrm{pH}_{2} \mathrm{~S}=1$ atm, $\mathrm{pH}=3.6-4.0$ and $25^{\circ} \mathrm{C}$ (Morse et al., 1987; Davison, 1991). An apparent solubility products of 2.6 for amorphous $\mathrm{FeS}$ in the Baltic Sea was determined in $15.8^{\circ} \mathrm{C}$ (Bagander and Carman, 1994). Recently, a solubility product constant of 3.00 \pm 0.12 was obtained at $20^{\circ} \mathrm{C}$ under various partial pressures of $\mathrm{H}_{2} \mathrm{~S}\left(10^{-1}, 10^{-3}, 10^{-4}, 10^{-5} \mathrm{MPa}\right)$ and $\mathrm{pH}$ values $(3.0-7.9)$ (Davison et al., 1999). According to the solubilities of iron sulfides mentioned above, anaerobic groundwaters of the Choshui fan-delta aquifers are saturated with respect to amorphous $\mathrm{FeS}$, which has a $-\log \mathrm{K}$ value of 3.00 .

We used the TDS, $\mathrm{pH}, \mathrm{HS}^{-}$and $\mathrm{Fe}^{+2}$ data for a total of 65 anaerobic groundwaters from seven aquifers in other regions (Thorstenson et al., 1979; Champ et al., 1979; Jackson and Patterson, 1982; Brown et al., 1999; Macalady et al., 1990; Zanini et al., 2000; Plummer and Sprinkle, 2001; Appendix 2) to calculate their respective IAPs of iron sulfides and then compared these values with our data. There are 16 samples of the total 65 data collected have $-\log$ (IAP) values greater than mackinawite's $\mathrm{pK}_{\mathrm{sp}} 3.55$ (25\% of all the samples) and are suggested to be saturated with respect to those more stable iron sulfide minerals than amorphous FeS. For these samples that $-\log$ (IAP) less than 3.55 (75\% of all the samples), the median value of $-\log (\mathrm{IAP})$ is 2.98 (Fig. 2E). Although TDS, pH, $\mathrm{HS}^{-}$ and $\mathrm{Fe}^{+2}$ are different for those aquifers, their median $-\log$ IAP value of these $75 \%$ data collected is similar to that obtained for the Choshui fan-delta aquifers (Fig. 2E). It is worthy to note that the aquifers used for these IAP calculations comprise a wide range of rock types and depositional environments such as the fan-delta alluvium (this study), limestone (Champ et al., 1979; Plummer and Sprinkle, 2001), river sand (Jackson and Patterson, 1982), coastal plain sediments (Brown et al., 1999), wetland (Macalady et al., 1990) and fractured carbonate rock (Zanini et al., 2000).

The solubility product of amorphous FeS noted in the database for the computer programs of WATEQF (Ball and Nordstrom, 1991) and PHREEQC (Parkhurst, 1995) is 3.91. However, the most commonly cited values for $-\log \mathrm{K}_{\mathrm{sp}}$ fall in the range from 2.90 to 3.00 (Morse et al., 1987; Davison, 1991; Stumm and Morgan, 1995; Davison et al.,1999). These values are consistent with the field measurements of our study. Furthermore, we found that at least the study made by Jackson and Patterson (1982) considered groundwater with a - logIAP value near 2.9 to be supersaturated with respect to amorphous FeS based on the WATEQF database.

The original solubility value of FeS used in WATEQF was taken from Berner (1967) (D.L. Parkhurst; personal communication). However, we found that WATEQF and PHREEQC misquoted Berner's $-\log \mathrm{K}_{\mathrm{sp}}$ as 3.91 , rather than 2.95. According to Garrels and Christ (1965) cited by Berner (1967), the dissolution constant $\left(\mathrm{K}_{\mathrm{d}}\right)$ for hydrogen sulfide is

$$
\mathrm{H}_{2} \mathrm{~S}_{\text {gas }}=\mathrm{H}_{2} \mathrm{~S}_{\mathrm{aq}} \quad-\log \mathrm{K}_{\mathrm{d}}=0.99
$$

The dissociation constant $(\mathrm{K})$ and the first acidity constant $\left(\mathrm{K}_{1}\right)$ for hydrogen sulfide are as follow 

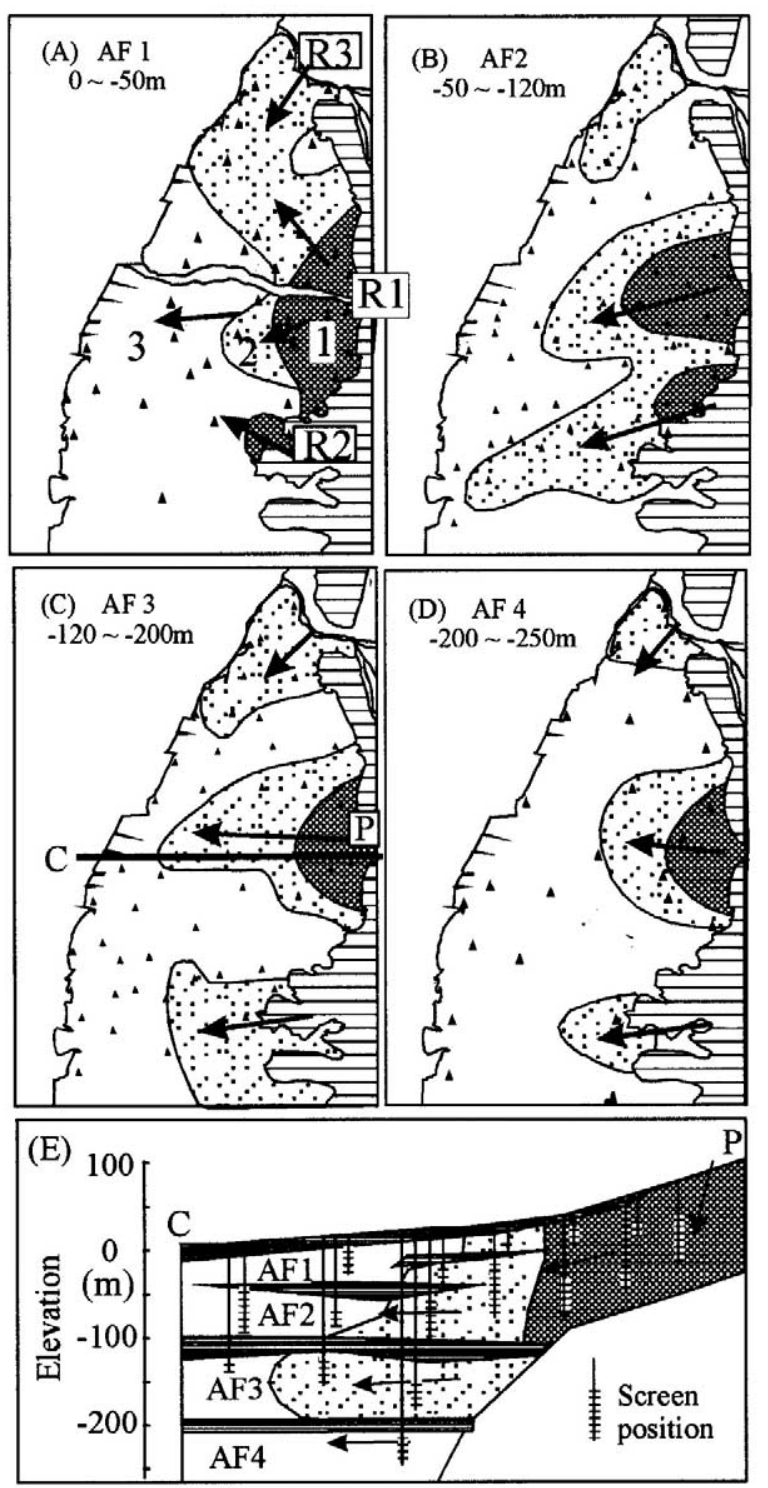

Legend

Recharge areas

R1 Choshui River

R2 Touliu Creek

R3 Wu Stream

\section{Redox zones}

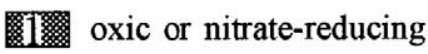

$2:-$ sulfide-detectable

3 sulfide-undetectable

4 Flow path

$\begin{array}{ll}\mathrm{AF} & \text { Aquifer } \\ \mathrm{CP} & \text { location of the Profile } \\ & \text { in Fig 3(E) }\end{array}$

Fig. 3. Redox zones of various aquifers in the Choshui fan-delta in terms of dissolved oxygen, nitrate and sulfide contents.

$$
\begin{gathered}
\mathrm{H}_{2} \mathrm{~S}_{\text {gas }}=2 \mathrm{H}^{+}+\mathrm{S}^{-2} \quad-\log \mathrm{K}=21.90 \quad \text { (Maronny, 1959) } \\
\mathrm{H}_{2} \mathrm{~S}_{\mathrm{aq}}=\mathrm{HS}^{-}+\mathrm{H}^{+} \quad-\log \mathrm{K}_{1}=6.99 \quad \text { (Berner, 1967) }
\end{gathered}
$$

The equation of amorphous FeS solubility used by Berner (1967) was

$$
\mathrm{FeS}=\mathrm{Fe}^{+2}+\mathrm{S}^{-2}-\log \mathrm{K}_{\mathrm{sp} 2}=16.87
$$

To avoid the uncertainty of the $-\log \mathrm{K}_{2}$ of $\mathrm{H}_{2} \mathrm{~S}$, it is expedient to define the solubility of amorphous $\mathrm{FeS}$, i.e., $-\log \mathrm{K}_{\mathrm{sp} 1}$ in terms of the following equation:

$$
\mathrm{FeS}+\mathrm{H}^{+}=\mathrm{Fe}^{+2}+\mathrm{HS}^{-}
$$

The $-\log \mathrm{K}_{\mathrm{sp} 1}$ calculated by eqn. (6), which is equal to eqns $(2)-(3)+(4)+(5)$ is 2.95 , not 3.915 as shown in the WATEQF's database.
Another difference between Berner's data and WATEQF's database is the second acidity constant $\left(-\log \mathrm{K}_{2}\right)$ of hydrogen sulfide:

$$
\mathrm{HS}^{-}=\mathrm{H}^{+}+\mathrm{S}^{-2}
$$

Equation (7) equals to $-(2)+(3)-(4)$, and $-\log K_{2}$ should be 13.92 instead of 12.918 as indicated in the WATEQF database.

The $-\operatorname{logIAP}$ values for the 46 samples from the Choshui fan-delta reveal a normal distribution with a mean value of 3.07 $\pm 0.34(1 \sigma)$ (Fig. 2F). We suggest that the variation in $-\log$ IAP values (standard deviation $=0.34$ ) of iron sulfide may be attributed to field sampling, preservation artifacts as well as analytical uncertainty. The analytical uncertainties in the determination of $\mathrm{Fe}^{+2}$ and sulfide in the lab were generally $\pm 10 \%$ and $\pm 15 \%$, respectively for the samples. These un- 

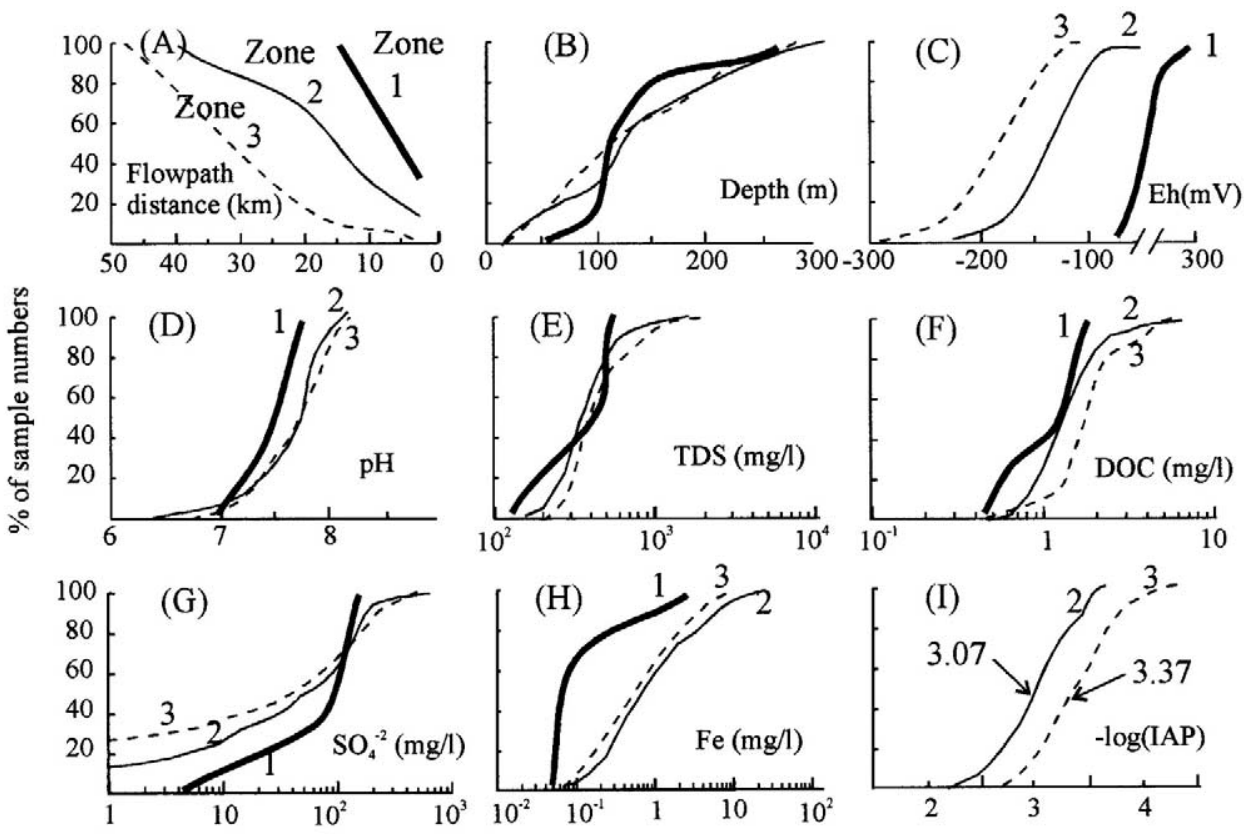

Fig. 4. Cumulative curves of various parameters for the three redox zones of the Choshui fan-delta (see text). There are 13, 46 and 114 samples in the first (heavy lines), second (light lines) and third (dash lines) zones, respectively.

certainties will produce an error of $\sim 0.1$ to 0.2 in the $-\log$ IAP values. Furthermore, sulfide concentration will decrease if a water sample is exposed to a trace of air and the $-\operatorname{logIAP}$ value will increase, i.e., the water will became undersaturated with respect to amorphous $\mathrm{FeS}$. In addition, $\mathrm{H}_{2} \mathrm{~S}$ and $\mathrm{CO}_{2}$ gases might be lost and $\mathrm{pH}$ values change while groundwaters are pumped from confined aquifers. Purging well water with a pump before sampling could raise fine-grained particles or colloidal suspension of FeS precipitations, parts of which could pass $0.45 \mu \mathrm{m}$ filters (Rickard, 1989). Such samples would show higher iron concentrations and thus lower - logIAP values because colloidal FeS precipitate would dissolve when nitric acid was added for sample preservation.

\section{REDOX ZONES OF CHOSHUI FAN-DELTA AQUIFERS}

Of the three streams recharging the Choshui fan-delta, the Choshui River is the largest, providing over $90 \%$ of the water to the upper fan (Liu, 1995; Chen and Liu, 2003). The other two streams, the $\mathrm{Wu}$ stream in the north and Touliu creek in the south are much smaller (Fig. 3). Based on dissolved oxygen, nitrate and sulfide contents, the aquifers in the Choshui fandelta can be divided into three redox zones along its flow path (Chen and Liu, 2003). The first zone (i.e., the upper fan), corresponding to the unconfined recharge region of the aquifer system, is oxic or nitrate-reducing with $\mathrm{Eh}>0 \mathrm{mV}$, dissolved oxygen $>0.5 \mathrm{mg} / \mathrm{L}$ or nitrate- $\mathrm{N}>0.5 \mathrm{mg} / \mathrm{L}$. The second zone (i.e., the middle fan) is anoxic (Eh $<0 \mathrm{mV}$ ) with detectable dissolved sulfide concentration. The third zone (i.e., the distal fan) is anoxic without detectable dissolved sulfide content (Fig. 3).

The median of measured Eh values for the three zones decreases down gradient from +55 , to -138 , to $-172 \mathrm{mV}$, respectively (Figs. 4A and 4C). The median Eh values of sulfideundetectable samples are substantially lower than those of sulfide- detectable samples. This indicates that the sulfide-undetectable groundwaters are more reducing, probably due to methanogenesis (Chapelle, 2001). The three zones are interpreted as corresponding to an oxic or nitrate-reduction zone, sulfate-reduction zone, and methanogenesis zone (Champ et al., 1979).

The differences in $\mathrm{pH}$ (Fig. 4D), TDS (Fig. 4E), DOC content (Fig. 4F), and aquifer depth (Fig. 4B) between the sulfide-detectable and sulfide-undetectable groundwater zones are negligible. The concentrations of sulfate (Fig. 4G) and iron (Fig. $4 \mathrm{H}$ ) of sulfide-undetectable groundwaters in the third zone are somewhat lower than those of sulfide-detectable groundwaters in the second zone.

The values of $-\log (\mathrm{IAP})$ for sulfide-undetectable groundwaters range from 2.67 to 4.42 , assuming a sulfide concentration of $0.03 \mathrm{mg} / \mathrm{L}$, which is the detection limit of our analytical method (Fig. 4I). These values represent possible minimum $-\log ($ IAP) values if groundwaters actually have very low sulfide concentrations. The median value of $-\log$ (IAP)s is $\sim 3.4$, indicating that the groundwaters studied are undersaturated with amorphous $\mathrm{FeS}(-\log \mathrm{K}=3.00)$.

Experiments conducted with oversaturated solutions show that solid amorphous iron sulfide $(\mathrm{FeS})$ forms very quickly (within seconds), followed by mackinawite crystals within several hours (Rickard, 1989). We suggest that the environment of a slowly flowing groundwater within a confined aquifer provides sufficient time for amorphous FeS to transform to mackinawite, and even pyrite. Groundwaters that are saturated with respect to amorphous $\mathrm{FeS}$, as indicated by the computed IAP, must therefore be ones in which dissolved sulfide species, such as $\mathrm{H}_{2} \mathrm{~S}$ or $\mathrm{HS}^{-}$, are being continuously produced, thus supplying sulfide for amorphous FeS precipitation. $\mathrm{H}_{2} \mathrm{~S}$ or $\mathrm{HS}^{-}$can form through sulfate reduction by organic matter oxidation under anaerobic conditions (such as the second zone of Fig. 3). If the supply of $\mathrm{H}_{2} \mathrm{~S}$ or $\mathrm{HS}^{-}$ceases and all 
amorphous FeS precipitates transform into allotropic minerals (e.g., mackinawite or pyrite), then values of $-\log (\mathrm{IAP})$ will be greater than 3.00 and new equilibrium states will be achieved. Such is likely the case for the third zone in the distal part of the fan-delta (Fig. 3).

\section{CONCLUSIONS}

The mean value of the ion activity product, represented as $-\operatorname{logIAP}$, of iron sulfides for 46 groundwater samples from the Choshui fan-delta is $3.07 \pm 0.34(1 \sigma)$, which is consistent with the solubility constant of amorphous FeS. This implies that the aquifers of sulfide-detectable anoxic groundwaters are still undergoing active sulfate-reduction processes.

The solubility constant $(-\log \mathrm{K})$ of amorphous $\mathrm{FeS}$ is $\sim 3.00$, which is different from the value of 3.91 adopted by the databases of WATEQF and PHREEQC. The error is attributed to the misquoting of Berner's data (Berner, 1967) by these two databases. Using WATEQF and PHREEQC computer programs, saturation indices (SI) for iron sulfides are thus an order of magnitude too high than those reported by Davison et al.(1999).

Aquifers of the Choshui fan-delta can be divided into three redox zones based on dissolved oxygen, nitrate and sulfide contents of groundwaters along flow paths. Groundwaters in the unconfined aquifer of the proximal zone (recharge area) are oxic or nitrate-reducing with $\mathrm{Eh}>0 \mathrm{mV}$, dissolved oxygen $>0.5 \mathrm{mg} / \mathrm{L}$ or nitrate- $\mathrm{N}>0.5 \mathrm{mg} / \mathrm{L}$. The second zone corresponds to the middle fan and is anoxic with $\mathrm{Eh}<0 \mathrm{mV}$ and detectable dissolved sulfide species. The third zone is also anoxic but dissolved sulfide species are undetectable. The medians of the Eh values for the first, second and third zones decrease down gradient from +55 , to -138 , to $-172 \mathrm{mV}$, respectively.

Acknowledgments-The authors wish to thank Profs. Y. Wang, S.W. Lin, Y.P. Chia and C.W. Liu, National Taiwan University, for their useful comments and suggestions. We also thank the anonymous reviewer, as well as Karen H. Johannesson, Donald Whittemore and associate editor, David J. Burdige, for their editorial comments and suggestions, which improved this manuscript considerably. This study is supported financially by National Science Council (NSC-89-2116M-002-010) and the Water Resources Agency, Ministry of Economic Affairs, Taiwan.

\section{Associate editor: D. Burdige}

\section{REFERENCES}

APHA. (1998) Standard methods for the examination of water and waste water $20^{\text {th }}$ ed. American Public Health Assoc., Washington, DC.

Bagander L. E. and Carman R. (1994) In situ determination of the apparent solubility product of amorphous iron sulphide. Appl. Geochem. 9/4, 379-38651.

Ball J. W. and Nordstrom D. K. (1991) User's manual for WATEQ4F, with revised thermodynamic data base and test cases for calculating speciation of major, trace and redox elements in natural waters. U.S.G.S. Open-File Report 91-183.

Benning L. G., Wilkin R. T., Barnes H. L. (2000) Reaction pathways in the Fe-S system below $100^{\circ} \mathrm{C}$. Chem. Geol. 167, 25-51.

Berner R. A. (1967) Thermodynamic stability of sedimentary iron sulfides. Am. J. Sci. 265, 773-785.

Berner R. A. (1970) Sedimentary pyrite formation. Am. J. Sci. 268, 1-23.

Brown C. J., Coates J. D., Schoonen M. A. A. (1999) Localized sulfate-reducing zones in a coastal plain aquifer. Ground Water $37 / 4,505-516$.
CGS. (1995) Hydrogeology of the Choshui fan. Central Geological Survey, MOEA, Taipei, Taiwan. (in Chinese).

Champ D. R., Gulens J., and Jackson R. E. (1979) Oxidation-reduction sequences in ground water flow systems. Can. J. Earth Sci. 16, 12-23.

Chapelle F. H. (2001) Ground-Water Microbiology and Geochemistry. John Wiley, New York, 477p.

Chen W. F. and Liu T. K. (2003) Dissolved oxygen and nitrate of groundwater in Choshui Fan-delta, western Taiwan. Env. Geol. 44, 731-737.

Davison W. (1980) A critical comparison of the measured solubilities of ferrous sulphide in natural waters. Geochim. Cosmochim. Acta 44, 803-808.

Davison W. (1991) The solubility of iron sulfides in synthetic and natural waters at ambient temperatures. Aqua. Sci. 35, 309-329.

Davison W., Phillips N., Tabner B. J. (1999) Soluble iron sulfide species in natural waters: reappraisal of their stoichiometry and stability constants. Aqua. Sci. 61, 23-43.

Douabul A. A. and Riley J. P. (1979) The solubility of gases in distilled water and seawater, V. Hydrogen sulphide. Deep-Sea Res. 26A $259-268$.

Garrels R. M. and Christ C. L. (1965) Solutions, minerals and equilibria. New York, Harper and Row.

Hem J. D. (1992) Study and interpretation of the chemical characteristics of natural water. U.S.G.S. Water-Sup. Paper 2254, 263p.

Jackson R. E. and Patterson R. J. (1982) Interpretation of pH and Eh trends in a fluvial-sand aquifer system. Water Res. Res. 18/4, $1255-1268$.

Langelier W. F. (1936) The analytical control of anticorrosion water treatment. Am. Water Works Assoc. J. 28, 1500-1521.

Liu T. K. (1995) Estimating flow and recharge rates of groundwater in western Taiwan using radiocarbon and tritium. Radiocarb. 37/2, 531-542.

Macalady D. L., Langmuir D., Brundl T., Elzerman A. (1990) Use of model-generated $\mathrm{Fe}^{3+}$ ion activities to compute Eh and Ferric oxyhydroxide solubilities in anaerobic systems. In Chem. modeling of aqueous systems II (ed. D. C. Melchior and R. L. Bassett), pp. 350-367. American Chem. Society

Maronny G. (1959) Constantes der dissociation de l'hydrogenene sulfure. Electrochim. Acta 1, 58-69.

Morse J. W., Millero F. J., Cornwell J. C., and Rickard D. (1987) The chemistry of the hydrogen sulfide and iron sulfide systems in natural waters. Earth Sci. Rev. 24, 1-42.

Parkhurst D. L. (1995) User's guide to PHREEQC - a computer program for speciation, reaction-path, advective-transport and inverse geochemical calculations. Water-Resources Investigations Report 95-4227, U.S.G.S., Lakewood, CO.

Plummer L. N. and Sprinkle C. L. (2001) Radiocarbon dating of dissolved inorganic carbon in groundwater from confined parts of the Upper Floridan aquifer, Florida, USA. Hydrogeol. J. 9, 127-150.

Rickard D. (1989) Experimental concentration-time curves for the iron(II) sulphide precipitation process in aqueous solutions and their interpretation. Chem. Geol. 78, 315-324.

Stumm W. and J. J. Morgan. (1995) Aquatic Chemistry, 3rd ed. John Wiley \& Sons, INC.

Sweeney R. E. and Kaplan I. R. (1973) Pyrite framboid formation: laboratory synthesis and marine sediments. Econ. Geol. 68, 618-634.

Thorstenson D. C., Fisher D. W. and Croft M. G. (1979) The geochemistry of the Fox Hills-Basal Hell Creek Aquifer in Southwestern North Dakota and Northwestern South Dakota. Water Res. Res. 15/6, 1479-1498.

Wilkin R. T. and Barnes H. L. (1996) Pyrite formation by reactions of iron monosulfides with dissolved inorganic and organic sulfur species. Geochim. Cosmochim. Acta 60, 4167-4179.

Wilkin R. T. and Barnes H. L. (1997) Formation processes of framboidal pyrite. Geochim. Cosmochim. Acta 61, 323-339.

WRA. (2000) Report of Groundwaters Head, Taiwan Groundwater Monitoring Network. Water Resources Agency, Ministry of Economic Affairs, Taipei, Taiwan.

Zanini L., Novakowski K. S., Lapcevic P., Bickerton G. S., Voralek J. and Talbot C. (2000) Ground water flow in a fractured carbonate aquifer inferred from combined hydrogeological and geochemical measurements. Ground Water 38/3, 350-360. 
Appendix 1 Data of groundwaters from the Choshui fan-delta.

\begin{tabular}{|c|c|c|c|c|c|c|c|c|c|c|c|c|c|}
\hline NO. & $\begin{array}{c}\mathrm{DO} \\
(\mathrm{mg} / \mathrm{l})\end{array}$ & $\begin{array}{c}\mathrm{Eh} \\
(\mathrm{mV})\end{array}$ & $\mathrm{pH}$ & $\begin{array}{c}\text { TDS } \\
(\mathrm{mg} / \mathrm{l})\end{array}$ & $\begin{array}{c}\text { Sulfate } \\
(\mathrm{mg} / \mathrm{l})\end{array}$ & $\begin{array}{l}\text { Sulfide } \\
(\mathrm{mg} / \mathrm{l})\end{array}$ & $\begin{array}{l}\mathrm{HS}^{-} \\
(\mathrm{mg} / \mathrm{l})\end{array}$ & $\begin{array}{c}\text { Nitrate-N } \\
(\mathrm{mg} / \mathrm{l})\end{array}$ & $\begin{array}{c}\mathrm{Fe} \\
(\mathrm{mg} / \mathrm{l})\end{array}$ & $\begin{array}{c}\text { DOC } \\
(\mathrm{mg} / \mathrm{l})\end{array}$ & $-\log$ IAP & $\begin{array}{c}\text { Depth } \\
\text { (m) }\end{array}$ & $\begin{array}{c}\text { Distance } \\
(\mathrm{km})\end{array}$ \\
\hline 1 & 0.1 & -200 & 7.92 & 720 & N.D. & N.D. & & 0.18 & 1.03 & 4.72 & & 82 & 40.0 \\
\hline 2 & 0.07 & -250 & 8.18 & 1073 & 34.6 & N.D. & & 0.11 & 0.34 & 3.99 & & 157 & 40.0 \\
\hline 3 & 0.1 & -280 & 8.27 & 410 & N.D. & N.D. & & 0.1 & 0.39 & 3.85 & & 237 & 40.0 \\
\hline 4 & 0.1 & -300 & 8.26 & 372 & N.D. & N.D. & & 0.17 & 0.76 & 5.07 & & 300 & 40.0 \\
\hline 5 & 0.08 & -195 & 7.80 & 543 & 34.6 & N.D. & & 0.16 & 2.17 & 3.72 & & 52 & 25.0 \\
\hline 6 & 0.09 & -150 & 7.84 & 427 & 40.8 & N.D. & & 0.11 & N.D. & 1.37 & & 90 & 25.0 \\
\hline 7 & 0.08 & -210 & 7.84 & 374 & 20.6 & N.D. & & 0.1 & 1.16 & 4.22 & & 156 & 25.0 \\
\hline 8 & 0.16 & -170 & 8.04 & 470 & 25 & N.D. & & 0.11 & 0.31 & 3.11 & & 278 & 25.0 \\
\hline 9 & 0.17 & -200 & 7.93 & 3058 & 78.2 & N.D. & & 0.13 & 0.51 & 3.9 & & 74 & 32.5 \\
\hline 10 & 0.07 & -200 & 8.03 & 304 & N.D. & N.D. & & 0.13 & 0.46 & 1.83 & & 168 & 32.5 \\
\hline 11 & 0.2 & -200 & 7.65 & 1469 & 25.9 & N.D. & & N.D. & 1.59 & 4.1 & & 90 & 38.5 \\
\hline 12 & 0.06 & -200 & 8.08 & 3150 & 118 & N.D. & & N.D. & 0.2 & 3.64 & & 165 & 38.5 \\
\hline 13 & 0.06 & -180 & 7.87 & 1782 & 33.1 & N.D. & & N.D. & 0.5 & 3.58 & & 215 & 38.5 \\
\hline 14 & 0.06 & -190 & 8.23 & 293 & N.D. & N.D. & & 0.07 & 0.13 & 2.68 & & 261 & 38.5 \\
\hline 15 & 0.43 & -190 & 7.55 & 274 & 3.31 & 0.11 & 0.08 & 0.25 & 0.74 & 3.6 & 3.08 & 48 & 10.0 \\
\hline 16 & 0.12 & -160 & 7.96 & 196 & N.D. & 0.08 & 0.07 & 0.21 & 0.29 & 2.4 & 3.11 & 162 & 10.0 \\
\hline 17 & 0.08 & -180 & 7.86 & 242 & N.D. & 0.14 & 0.12 & 0.14 & 1.12 & 1.12 & 2.41 & 210 & 10.0 \\
\hline 18 & 0.1 & -170 & 7.84 & 218 & N.D. & 0.08 & 0.07 & 0.18 & 0.57 & 1.42 & 2.95 & 282 & 10.0 \\
\hline 19 & 0.03 & -200 & 7.87 & 376 & N.D. & N.D. & & 0.14 & 1.14 & 2.06 & & 73 & 32.5 \\
\hline 20 & 0.04 & -128 & 8.1 & 244 & N.D. & N.D. & & 0.12 & 0.09 & 1.56 & & 213 & 32.5 \\
\hline 21 & 0.03 & -190 & 7.65 & 398 & N.D. & N.D. & & 0.15 & 1.83 & 4.96 & & 78 & 28.5 \\
\hline 22 & 0.04 & -180 & 8.07 & 250 & N.D. & N.D. & & 0.11 & 0.16 & 1.68 & & 197 & 28.5 \\
\hline 23 & 0.41 & -180 & 7.67 & 22800 & 1257 & N.D. & & 0.11 & 2.36 & 5.74 & & 47 & 38.5 \\
\hline 24 & 0.05 & -220 & 8.15 & 896 & 38.4 & N.D. & & N.D. & 0.33 & 2.56 & & 142 & 38.5 \\
\hline 25 & 0.32 & -210 & 7.68 & 302 & N.D. & 0.06 & 0.05 & N.D. & 2.2 & 2.63 & 2.69 & 103 & 24.0 \\
\hline 26 & 0.51 & -260 & 7.88 & 271 & N.D. & N.D. & & N.D. & 0.48 & 1.2 & & 180 & 24.0 \\
\hline 27 & 0.19 & -136 & 7.11 & 447 & 91.2 & N.D. & & 4.09 & 2.19 & 1.86 & & 40 & 6.0 \\
\hline 28 & 0.18 & -152 & 7.25 & 140 & 5.76 & 0.05 & 0.03 & N.D. & 3.65 & 0.5 & 3.07 & 169 & 6.0 \\
\hline 29 & 0.13 & -174 & 7.58 & 288 & 2.4 & N.D. & & 0.12 & 4.47 & 3.98 & & 93 & 18.5 \\
\hline 30 & 0.11 & -179 & 7.97 & 201 & 1.92 & 0.06 & 0.05 & N.D. & 0.44 & 1.26 & 3.07 & 182 & 18.5 \\
\hline 31 & 0.1 & -180 & 7.73 & 284 & 1.92 & N.D. & & 0.15 & 2.43 & 1.38 & & 80 & 32.0 \\
\hline 32 & 0.11 & -270 & 8.06 & 225 & N.D. & N.D. & & 0.1 & 0.44 & 2.27 & & 163 & 32.0 \\
\hline 33 & 1.59 & -18 & 7.42 & 182 & 9.6 & 0.04 & & 0.66 & 2.87 & 0.6 & & 102 & 2.5 \\
\hline 34 & 0.21 & -114 & 6.76 & 114 & 37 & 0.09 & 0.03 & 0.32 & 12 & 0.74 & 3.04 & 157 & 2.5 \\
\hline 35 & 0.27 & -154 & 7.14 & 198 & N.D. & N.D. & & 0.28 & 7.09 & 2.24 & & 70 & 9.0 \\
\hline 36 & 0.11 & -143 & 6.6 & 350 & N.D. & N.D. & & 0.15 & 5.13 & 2.25 & & 140 & 9.0 \\
\hline 37 & 0.23 & -123 & 7.34 & 194 & 7.68 & N.D. & & 0.13 & 2.37 & 2.28 & & 206 & 9.0 \\
\hline 38 & 0.22 & -138 & 7.28 & 942 & 226 & N.D. & & 0.17 & 7.46 & 4.24 & & 28 & 15.0 \\
\hline 39 & 0.21 & -140 & 7.74 & 393 & 28.3 & N.D. & & 0.13 & 6.76 & 4.06 & & 64 & 15.0 \\
\hline 40 & 0.23 & -145 & 7.72 & 282 & N.D. & 0.04 & 0.03 & 0.08 & 4.06 & 3.8 & 2.60 & 104 & 15.0 \\
\hline 41 & 0.15 & -129 & 7.6 & 200 & 4.32 & N.D. & & 0.16 & 1.62 & 0.76 & & 198 & 15.0 \\
\hline 42 & 0.13 & -129 & 7.92 & 250 & 12 & 0.06 & 0.05 & 0.1 & 0.29 & 1.84 & 3.32 & 294 & 15.0 \\
\hline 43 & 0.04 & -250 & 7.98 & 749 & 10.1 & N.D. & & N.D. & 0.7 & 4.5 & & 60 & 41.0 \\
\hline 44 & 0.05 & -205 & 8.21 & 282 & N.D. & N.D. & & 0.34 & 0.15 & 1.51 & & 146 & 41.0 \\
\hline 45 & 0.07 & -170 & 8.18 & 302 & N.D. & N.D. & & 0.25 & 0.16 & 1.58 & & 206 & 41.0 \\
\hline 46 & 7.63 & 79 & 6.96 & 229 & 36 & N.D. & & 7.41 & 0.09 & 0.64 & & 102 & 5.0 \\
\hline 47 & 0.13 & -118 & 6.96 & 349 & 72 & N.D. & & 0.24 & 16.3 & 2.29 & & 32 & 6.0 \\
\hline 48 & 0.32 & 47 & 7.11 & 262 & 50.4 & N.D. & & 3.1 & 0.18 & 1.58 & & 96 & 6.0 \\
\hline 49 & 0.13 & -180 & 7.55 & 286 & N.D. & N.D. & & N.D. & 3.23 & 1.68 & & 81 & 22.5 \\
\hline 50 & 0.16 & -200 & 8.03 & 264 & N.D. & 0.05 & 0.04 & N.D. & 0.32 & 1.48 & 3.26 & 126 & 22.5 \\
\hline 51 & 0.46 & -136 & 7.46 & 1085 & 320 & N.D. & & 0.14 & 5.93 & 2.86 & & 29 & 27.5 \\
\hline 52 & 0.3 & -219 & 7.85 & 302 & 7.68 & N.D. & & 0.21 & 1.32 & 1.84 & & 78 & 27.5 \\
\hline 53 & 0.21 & -160 & 7.94 & 286 & N.D. & N.D. & & 0.11 & 0.28 & 1.46 & & 126 & 27.5 \\
\hline 54 & 0.64 & -160 & 8.07 & 244 & N.D. & N.D. & & 0.07 & 0.16 & 1.74 & & 175 & 27.5 \\
\hline 55 & 0.2 & -170 & 8.14 & 267 & N.D. & N.D. & & 0.07 & 0.18 & 1.44 & & 258 & 27.5 \\
\hline 56 & 0.37 & -226 & 8.03 & 642 & 105 & N.D. & & 0.08 & 0.61 & 4.06 & & 48 & 47.5 \\
\hline 57 & 0.08 & -160 & 8.01 & 273 & N.D. & N.D. & & 0.09 & 0.39 & 1.72 & & 114 & 47.5 \\
\hline 58 & 0.07 & -160 & 8.07 & 251 & 7.68 & N.D. & & 0.08 & 0.14 & 1.35 & & 162 & 47.5 \\
\hline 59 & 0.05 & -150 & 8.08 & 277 & 3.84 & N.D. & & 0.09 & 0.17 & 1.38 & & 216 & 47.5 \\
\hline 60 & 4 & 60 & 6.95 & 248 & 62.9 & N.D. & & N.D. & 0.95 & 0.58 & & 57 & 2.5 \\
\hline 61 & 3.48 & 59 & 7.15 & 278 & 73.4 & N.D. & & 7.23 & N.D. & 0.44 & & 102 & 2.5 \\
\hline 62 & 0.07 & -168 & 7.59 & 213 & 3.36 & N.D. & & 0.11 & 1.31 & 0.58 & & 252 & 2.5 \\
\hline 63 & 0.13 & -210 & 7.62 & 506 & 129 & N.D. & & 0.13 & 2.16 & 2.04 & & 68 & 25.0 \\
\hline 64 & 0.17 & -147 & 7.43 & 427 & 113 & N.D. & & 0.14 & 2.14 & 1.84 & & 102 & 25.0 \\
\hline 65 & 0.51 & -200 & 7.54 & 310 & 61.5 & N.D. & & 0.1 & 1.2 & 1.5 & & 50 & 30.0 \\
\hline 66 & 0.33 & -164 & 7.66 & 287 & 41.8 & N.D. & & 0.07 & 1 & 1.64 & & 124 & 30.0 \\
\hline 67 & 0.16 & -118 & 7.43 & 745 & 219 & N.D. & & 0.1 & 2.6 & 2.02 & & 31 & 33.5 \\
\hline
\end{tabular}


Appendix (Continued)

\begin{tabular}{|c|c|c|c|c|c|c|c|c|c|c|c|c|c|}
\hline NO. & $\begin{array}{c}\mathrm{DO} \\
(\mathrm{mg} / \mathrm{l})\end{array}$ & $\begin{array}{c}\mathrm{Eh} \\
(\mathrm{mV})\end{array}$ & $\mathrm{pH}$ & $\begin{array}{c}\text { TDS } \\
(\mathrm{mg} / \mathrm{l})\end{array}$ & $\begin{array}{c}\text { Sulfate } \\
(\mathrm{mg} / \mathrm{l})\end{array}$ & $\begin{array}{c}\text { Sulfide } \\
(\mathrm{mg} / \mathrm{l})\end{array}$ & $\begin{array}{l}\mathrm{HS}^{-} \\
(\mathrm{mg} / \mathrm{l})\end{array}$ & $\begin{array}{l}\text { Nitrate-N } \\
(\mathrm{mg} / \mathrm{l})\end{array}$ & $\begin{array}{c}\mathrm{Fe} \\
(\mathrm{mg} / \mathrm{l})\end{array}$ & $\begin{array}{c}\mathrm{DOC} \\
(\mathrm{mg} / \mathrm{l})\end{array}$ & $-\log$ IAP & $\begin{array}{l}\text { Depth } \\
\text { (m) }\end{array}$ & $\begin{array}{l}\text { Distance } \\
(\mathrm{km})\end{array}$ \\
\hline 68 & 0.17 & -136 & 7.56 & 524 & 144 & N.D. & & 0.1 & 1.32 & 1.83 & & 218 & 33.5 \\
\hline 69 & 0.27 & -231 & 7.92 & 286 & N.D. & N.D. & & 0.08 & 1.11 & 1.93 & & 110 & 42.5 \\
\hline 70 & 0.13 & -195 & 8.1 & 248 & N.D. & N.D. & & N.D. & 0.18 & 1.54 & & 195 & 42.5 \\
\hline 71 & 0.19 & -236 & 7.7 & 4566 & 291 & N.D. & & N.D. & 2.75 & 1.96 & & 42 & 48.5 \\
\hline 72 & 0.27 & -199 & 7.96 & 717 & 25 & N.D. & & N.D. & 0.34 & 2 & & 98 & 48.5 \\
\hline 73 & 0.13 & -180 & 8.18 & 292 & N.D. & N.D. & & N.D. & 0.14 & 1.38 & & 196 & 48.5 \\
\hline 74 & 0.1 & -192 & 8.2 & 284 & N.D. & N.D. & & N.D. & 0.08 & 1.4 & & 276 & 48.5 \\
\hline 75 & 0.2 & -120 & 8.25 & 368 & 6.72 & N.D. & & N.D. & 0.08 & 1.4 & & 67 & 5.0 \\
\hline 76 & 0.3 & -150 & 8.29 & 331 & 17.8 & N.D. & & 0.11 & 0.2 & 1.85 & & 114 & 5.0 \\
\hline 77 & 0.41 & -4 & 6.44 & 188 & 48.5 & 0.07 & 0.01 & 0.14 & 13 & 1.47 & 3.83 & 15 & 10.0 \\
\hline 78 & 0.15 & -91 & 6.92 & 180 & 13.4 & 0.07 & 0.03 & 0.18 & 8.09 & 1.78 & 3.07 & 114 & 10.0 \\
\hline 79 & 0.88 & 14 & 7.29 & 375 & 56.6 & 0.06 & 0.04 & N.D. & 1.74 & 2.24 & 3.29 & 21 & 15.0 \\
\hline 80 & 0.15 & -82 & 7.36 & 193 & 36.5 & 0.05 & 0.04 & N.D. & 2.12 & 1.18 & 3.09 & 123 & 15.0 \\
\hline 81 & 0.13 & -85 & 7.67 & 246 & 17.3 & 0.05 & 0.04 & N.D. & 0.58 & 1.32 & 3.36 & 224 & 15.0 \\
\hline 82 & 0.16 & -98 & 7.9 & 223 & 14.4 & 0.06 & 0.05 & N.D. & 0.2 & 1.22 & 3.49 & 294 & 15.0 \\
\hline 83 & 0.32 & 41 & 7.5 & 611 & 137 & N.D. & & 10.4 & 0.21 & 0.84 & & 186 & 5.0 \\
\hline 84 & 0.3 & -148 & 8.11 & 326 & 35 & N.D. & & 0.15 & N.D. & 1.31 & & 89 & 5.0 \\
\hline 85 & 2.78 & -21 & 8.12 & 309 & 28.8 & N.D. & & 0.07 & N.D. & 1.36 & & 174 & 5.0 \\
\hline 86 & 4.56 & 282 & 7.56 & 471 & 116 & N.D. & & 7.05 & 0.18 & 1.42 & & 94 & 4.5 \\
\hline 87 & 1.5 & 97 & 7.66 & 438 & 106 & N.D. & & 3.46 & 0.06 & 1.2 & & 54 & 7.5 \\
\hline 88 & 1.2 & 50 & 7.48 & 566 & 133 & N.D. & & 8.02 & N.D. & 1.61 & & 114 & 7.5 \\
\hline 89 & 0.91 & -164 & 7.58 & 603 & 162 & N.D. & & 0.1 & 2.24 & 1.59 & & 32 & 15.0 \\
\hline 90 & 0.87 & -78 & 7.64 & 480 & 109 & N.D. & & 1.26 & N.D. & 1.3 & & 136 & 15.0 \\
\hline 91 & 0.15 & -151 & 7.4 & 710 & 157 & 0.04 & 0.03 & 0.1 & 5.01 & 2.02 & 2.90 & 20 & 24.0 \\
\hline 92 & 0.12 & -171 & 7.74 & 379 & 91.7 & 0.04 & 0.03 & 0.07 & 1.24 & 1.39 & 3.12 & 115 & 24.0 \\
\hline 93 & 0.24 & -112 & 8.03 & 374 & 60 & N.D. & & N.D. & 0.23 & 1.48 & & 191 & 24.0 \\
\hline 94 & 0.17 & -230 & 7.56 & 612 & 133 & N.D. & & N.D. & 2.58 & 1.74 & & 36 & 35.0 \\
\hline 95 & 0.14 & -206 & 7.75 & 309 & 34.6 & 0.05 & 0.04 & N.D. & 1.52 & 1.53 & 2.88 & 97 & 35.0 \\
\hline 96 & 0.14 & -157 & 8.1 & 268 & 8.16 & N.D. & & 0.08 & 0.16 & 1.56 & & 274 & 35.0 \\
\hline 97 & 0.13 & -169 & 7.79 & 323 & 86.4 & N.D. & & N.D. & 0.54 & 1.38 & & 66 & 36.5 \\
\hline 98 & 0.13 & -166 & 7.86 & 328 & 66.7 & N.D. & & N.D. & 0.25 & 1.28 & & 115 & 36.5 \\
\hline 99 & 0.13 & -146 & 8.07 & 242 & 10.1 & N.D. & & N.D. & N.D. & 1.38 & & 197 & 36.5 \\
\hline 100 & 0.23 & -165 & 7.7 & 319 & 25.4 & N.D. & & N.D. & 0.52 & 1.56 & & 120 & 45.0 \\
\hline 101 & 0.09 & -197 & 8.12 & 282 & N.D. & N.D. & & N.D. & 0.13 & 1.7 & & 220 & 45.0 \\
\hline 102 & 0.16 & -208 & 7.84 & 300 & 5.28 & N.D. & & N.D. & 0.82 & 1.84 & & 70 & 43.0 \\
\hline 103 & 0.15 & -160 & 8.06 & 272 & 8.64 & N.D. & & 0.35 & 0.12 & 1.76 & & 178 & 43.0 \\
\hline 104 & 0.08 & -179 & 7.4 & 814 & 309 & 0.03 & 0.02 & N.D. & 3.95 & 1.94 & 3.19 & 38 & 19.0 \\
\hline 105 & 2.02 & -161 & 7.68 & 474 & 142 & 0.03 & 0.02 & N.D. & 1.32 & 1.2 & 3.34 & 114 & 19.0 \\
\hline 106 & 0.16 & -191 & 7.87 & 375 & 91.7 & 0.13 & 0.11 & N.D. & 0.68 & 1.52 & 2.68 & 64 & 25.0 \\
\hline 107 & 0.06 & -182 & 7.81 & 384 & 85 & 0.05 & 0.04 & N.D. & 1.14 & 1.24 & 2.96 & 140 & 25.0 \\
\hline 108 & 0.1 & -156 & 7.99 & 298 & 61.9 & 0.08 & 0.07 & N.D. & 0.1 & 1.52 & 3.57 & 210 & 25.0 \\
\hline 109 & 0.09 & -176 & 8.04 & 348 & 49.9 & N.D. & & N.D. & 0.14 & 1.3 & & 268 & 25.0 \\
\hline 110 & 0.12 & -151 & 7.53 & 970 & 286 & N.D. & & 0.1 & 2.46 & 2.32 & & 48 & 33.5 \\
\hline 111 & 0.13 & -179 & 7.75 & 405 & 105 & N.D. & & N.D. & 0.54 & 1.66 & & 97 & 33.5 \\
\hline 112 & 0.13 & -156 & 7.93 & 316 & 56.6 & 0.04 & 0.04 & N.D. & 0.16 & 1.76 & 3.68 & 174 & 33.5 \\
\hline 113 & 0.11 & -202 & 7.77 & 304 & 7.68 & N.D. & & N.D. & 0.83 & 1.8 & & 104 & 42.0 \\
\hline 114 & 0.07 & -194 & 8.03 & 252 & 13.4 & N.D. & & N.D. & 0.21 & 1.36 & & 174 & 42.0 \\
\hline 115 & 0.34 & -89 & 7.06 & 460 & 86.4 & N.D. & & 2.13 & 0.74 & 1.94 & & 18 & 2.5 \\
\hline 116 & 0.28 & 77 & 7.22 & 390 & 43.7 & N.D. & & 7.24 & 0.09 & 1.42 & & 96 & 2.5 \\
\hline 117 & 0.07 & -11 & 7.92 & 259 & 11 & N.D. & & 0.27 & 0.92 & 1.88 & & 186 & 2.5 \\
\hline 118 & 0.2 & -120 & 7.95 & 314 & 138 & N.D. & & 0.26 & 0.22 & 1.1 & & 72 & 2.5 \\
\hline 119 & 0.4 & -150 & 7.77 & 346 & 146 & N.D. & & 0.15 & 0.07 & 1 & & 186 & 2.5 \\
\hline 120 & 6.48 & 181 & 7.09 & 146 & 11.5 & N.D. & & 8.99 & 1.14 & 1.82 & & 120 & 2.5 \\
\hline 121 & 0.94 & 100 & 7.34 & 122 & 4.8 & N.D. & & 1.41 & 0.28 & 0.56 & & 240 & 2.5 \\
\hline 122 & 6.22 & 110 & 7.07 & 350 & 69.1 & N.D. & & 8.47 & 0.08 & 0.44 & & 108 & 2.5 \\
\hline 123 & 0.33 & 33 & 7.35 & 678 & 186 & N.D. & & 4.8 & 0.1 & 1.38 & & 32 & 10.5 \\
\hline 124 & 2.3 & 16 & 7.72 & 475 & 159 & N.D. & & 4.56 & 0.06 & 1.22 & & 102 & 10.5 \\
\hline 125 & 0.37 & -120 & 7.08 & 919 & 237 & N.D. & & 0.26 & 7.63 & 1.46 & & 28 & 17.5 \\
\hline 126 & 0.49 & -158 & 7.66 & 429 & 132 & 0.06 & 0.05 & 0.13 & 1.3 & 1.08 & 2.96 & 58 & 17.5 \\
\hline 127 & 0.25 & -174 & 7.73 & 398 & 123 & 0.09 & 0.07 & 0.08 & 0.86 & 1.46 & 2.92 & 126 & 17.5 \\
\hline 128 & 1.97 & -6 & 7.57 & 533 & 141 & N.D. & & 6.79 & 0.07 & 1.4 & & 134 & 10.0 \\
\hline 129 & 1.83 & 29 & 7.47 & 520 & 148 & N.D. & & 7.16 & N.D. & 1.48 & & 266 & 10.0 \\
\hline 130 & 0.05 & -164 & 7.38 & 866 & 341 & N.D. & & 0.14 & 5.68 & 1.74 & & 29 & 22.5 \\
\hline 131 & 0.07 & -136 & 7.81 & 443 & 142 & 0.04 & 0.03 & 0.16 & 0.89 & 1.69 & 3.20 & 125 & 22.5 \\
\hline 132 & 0.58 & -134 & 7.83 & 539 & 138 & N.D. & & 0.14 & 0.83 & 1.86 & & 63 & 34.0 \\
\hline 133 & 0.26 & -133 & 7.83 & 352 & 94.1 & N.D. & & 0.14 & 0.54 & 1.58 & & 116 & 34.0 \\
\hline 134 & 0.18 & -153 & 7.91 & 520 & 116 & N.D. & & 0.13 & 0.86 & 1.88 & & 58 & 39.0 \\
\hline
\end{tabular}


Appendix (Continued)

\begin{tabular}{|c|c|c|c|c|c|c|c|c|c|c|c|c|c|}
\hline NO. & $\begin{array}{c}\mathrm{DO} \\
(\mathrm{mg} / \mathrm{l})\end{array}$ & $\begin{array}{c}\mathrm{Eh} \\
(\mathrm{mV})\end{array}$ & $\mathrm{pH}$ & $\begin{array}{c}\text { TDS } \\
(\mathrm{mg} / \mathrm{l})\end{array}$ & $\begin{array}{c}\text { Sulfate } \\
(\mathrm{mg} / \mathrm{l})\end{array}$ & $\begin{array}{l}\text { Sulfide } \\
(\mathrm{mg} / \mathrm{l})\end{array}$ & $\begin{array}{l}\mathrm{HS}^{-} \\
(\mathrm{mg} / \mathrm{l})\end{array}$ & $\begin{array}{c}\text { Nitrate-N } \\
(\mathrm{mg} / \mathrm{l})\end{array}$ & $\begin{array}{c}\mathrm{Fe} \\
(\mathrm{mg} / \mathrm{l})\end{array}$ & $\begin{array}{c}\mathrm{DOC} \\
(\mathrm{mg} / \mathrm{l})\end{array}$ & $-\log$ IAP & $\begin{array}{l}\text { Depth } \\
\text { (m) }\end{array}$ & $\begin{array}{c}\text { Distance } \\
(\mathrm{km})\end{array}$ \\
\hline 135 & 0.11 & -160 & 7.84 & 480 & 102 & 0.05 & 0.04 & 0.6 & 0.35 & 2.08 & 3.46 & 148 & 39.0 \\
\hline 136 & 0.11 & -159 & 7.26 & 450 & 120 & N.D. & & 0.21 & 0.44 & 1.25 & & 106 & 39.0 \\
\hline 137 & 0.14 & -151 & 8.22 & 311 & 32.2 & N.D. & & 0.13 & 0.14 & 1.96 & & 200 & 39.0 \\
\hline 138 & 0.13 & -173 & 7.78 & 310 & 80 & N.D. & & 0.02 & 0.11 & 1.85 & & 275 & 39.0 \\
\hline 139 & 0.14 & -89 & 7.41 & 708 & 195 & 0.08 & 0.06 & 0.12 & 2.88 & 1.4 & 2.83 & 30 & 17.0 \\
\hline 140 & 0.19 & -124 & 7.86 & 408 & 104 & 0.07 & 0.06 & N.D. & 0.38 & 1.18 & 3.21 & 240 & 17.0 \\
\hline 141 & 0.08 & -92 & 7.31 & 992 & 253 & 0.07 & 0.05 & 0.08 & 5.33 & 1.39 & 2.78 & 21 & 22.5 \\
\hline 142 & 0.05 & -125 & 8.01 & 368 & 128 & 0.1 & 0.09 & N.D. & 0.15 & 1.2 & 3.28 & 227 & 22.5 \\
\hline 143 & 0.03 & -106 & 7.94 & 412 & 117 & N.D. & & N.D. & 0.11 & 1.16 & & 276 & 22.5 \\
\hline 144 & 0.66 & -255 & 7.25 & 1175 & 593 & N.D. & & 0.13 & 0.66 & 1.9 & & 33 & 32.0 \\
\hline 145 & 0.44 & -276 & 7.97 & 393 & 97.4 & N.D. & & 0.14 & 0.21 & 1.6 & & 218 & 32.0 \\
\hline 146 & 0.66 & -580 & 7.95 & 452 & 118 & N.D. & & 0.09 & 0.29 & 2.19 & & 67 & 37.5 \\
\hline 147 & 0.9 & -224 & 7.86 & 399 & 121 & N.D. & & 0.09 & 0.22 & 2 & & 110 & 37.5 \\
\hline 148 & 0.51 & -268 & 7.94 & 322 & 97.4 & N.D. & & 0.08 & 0.39 & 1.86 & & 205 & 37.5 \\
\hline 149 & 0.09 & -134 & 7.54 & 190 & N.D. & N.D. & & N.D. & 2.33 & 0.51 & & 69 & 19.0 \\
\hline 150 & 0.09 & -124 & 7.59 & 171 & N.D. & N.D. & & N.D. & 1.17 & 0.49 & & 121 & 19.0 \\
\hline 151 & 0.06 & -178 & 7.85 & 233 & 2.88 & N.D. & & N.D. & 0.55 & 0.46 & & 140 & 19.0 \\
\hline 152 & 0.05 & -141 & 7.96 & 216 & N.D. & N.D. & & N.D. & 0.23 & 0.59 & & 198 & 19.0 \\
\hline 153 & 0.37 & -296 & 7.61 & 438 & 98.4 & N.D. & & N.D. & 1.44 & 2.14 & & 69 & 25.0 \\
\hline 154 & 0.34 & -207 & 7.68 & 440 & 91.7 & N.D. & & N.D. & 0.89 & 1.96 & & 103 & 25.0 \\
\hline 155 & 0.2 & -293 & 7.9 & 471 & 118 & N.D. & & N.D. & 0.41 & 2.44 & & 224 & 25.0 \\
\hline 156 & 0.59 & -273 & 7.65 & 564 & 170 & N.D. & & 0.07 & 1.01 & 1.83 & & 83 & 32.5 \\
\hline 157 & 0.36 & -244 & 7.8 & 387 & 128 & N.D. & & 0.09 & 0.52 & 1.96 & & 115 & 32.5 \\
\hline 158 & 0.21 & -262 & 7.88 & 409 & 133 & N.D. & & 0.08 & 0.25 & 1.73 & & 198 & 32.5 \\
\hline 159 & 0.42 & -141 & 7.59 & 634 & 178 & N.D. & & 0.09 & 2.43 & 2.37 & & 66 & 30.0 \\
\hline 160 & 0.2 & -94 & 7.73 & 323 & 87.4 & N.D. & & N.D. & 0.27 & 2.16 & & 120 & 30.0 \\
\hline 161 & 0.29 & -135 & 7.87 & 375 & 91.2 & N.D. & & N.D. & 0.37 & 1.98 & & 204 & 30.0 \\
\hline 162 & 0.39 & -122 & 8.05 & 220 & 24.5 & N.D. & & N.D. & 0.28 & 2.33 & & 278 & 30.0 \\
\hline 163 & 1.51 & -92 & 7.47 & 2369 & 1299 & N.D. & & N.D. & 8.72 & 2.9 & & 17 & 35.0 \\
\hline 164 & 0.32 & -151 & 7.57 & 1076 & 490 & 0.06 & 0.05 & 0.15 & 3.7 & 1.39 & 2.60 & 60 & 35.0 \\
\hline 165 & 0.22 & -135 & 7.81 & 422 & 128 & 0.07 & 0.06 & 0.12 & 0.6 & 0.82 & 3.00 & 120 & 35.0 \\
\hline 166 & 0.24 & -120 & 7.88 & 386 & 118 & 0.07 & 0.06 & 0.1 & 0.33 & 0.82 & 3.18 & 204 & 35.0 \\
\hline 167 & 0.4 & -148 & 7.71 & 472 & 86.4 & N.D. & & 0.22 & 0.16 & 1.64 & & 71 & 39.0 \\
\hline 168 & 0.21 & -161 & 7.93 & 444 & 97.9 & N.D. & & N.D. & 0.18 & 0.82 & & 115 & 39.0 \\
\hline 169 & 0.89 & -153 & 7.97 & 371 & 94.6 & N.D. & & N.D. & 0.16 & 0.86 & & 197 & 39.0 \\
\hline 170 & 0.2 & -179 & 8.06 & 314 & 63.8 & N.D. & & N.D. & 0.07 & 1.04 & & 284 & 39.0 \\
\hline 171 & 0.2 & -150 & 7.36 & 754 & 47 & N.D. & & N.D. & 5.76 & 1.33 & & 20 & 27.5 \\
\hline 172 & 0.13 & -114 & 6.95 & 249 & 23.5 & N.D. & & 0.52 & 21.5 & 7.88 & & 65 & 27.5 \\
\hline 173 & 0.46 & -204 & 7.44 & 157 & N.D. & N.D. & & N.D. & 1.32 & 0.62 & & 130 & 27.5 \\
\hline 174 & 0.19 & -242 & 8.02 & 283 & N.D. & N.D. & & N.D. & 0.22 & 0.9 & & 294 & 27.5 \\
\hline 175 & 0.18 & -145 & 7.63 & 208 & N.D. & N.D. & & 0.19 & 2.59 & 0.55 & & 125 & 12.5 \\
\hline 176 & 0.28 & -93 & 7.94 & 256 & N.D. & 0.04 & 0.03 & 0.14 & 0.31 & 0.56 & 3.49 & 174 & 12.5 \\
\hline 177 & 0.2 & -173 & 7.86 & 449 & 39.4 & 0.06 & 0.05 & N.D. & 0.84 & 1.65 & 2.96 & 34 & 17.5 \\
\hline 178 & 0.83 & -101 & 7.9 & 334 & 78.7 & N.D. & & N.D. & 0.21 & 1.06 & & 120 & 17.5 \\
\hline 179 & 0.25 & -130 & 7.97 & 244 & 42.2 & 0.07 & 0.06 & N.D. & 0.24 & 0.86 & 3.27 & 198 & 17.5 \\
\hline 180 & 0.26 & 4 & 6.83 & 356 & 84.5 & N.D. & & 2.1 & 0.16 & 0.72 & & 30 & 2.5 \\
\hline 181 & 0.34 & -100 & 8.19 & 248 & 12 & 0.14 & 0.13 & 0.15 & 0.79 & 1.04 & 2.20 & 126 & 2.5 \\
\hline 182 & 2.56 & -75 & 8.14 & 286 & 8.64 & N.D. & & 0.13 & 1.59 & 0.76 & & 197 & 2.5 \\
\hline 183 & 1.06 & -123 & 7.55 & 600 & 141 & N.D. & & 0.18 & 3.63 & 1.08 & & 28 & 7.5 \\
\hline 185 & 0.23 & -130 & 8.14 & 352 & 32.2 & 0.07 & 0.06 & 0.11 & 0.22 & 2.18 & 3.16 & 117 & 7.5 \\
\hline 186 & 0.44 & -133 & 8.1 & 282 & 14.9 & 0.08 & 0.07 & 0.17 & 0.27 & 1.04 & 3.03 & 194 & 7.5 \\
\hline 187 & 0.37 & -104 & 7.51 & 552 & 97.4 & 0.04 & 0.03 & 0.2 & 2.97 & 0.76 & 3.00 & 17 & 2.5 \\
\hline 188 & 0.22 & -70 & 7.88 & 431 & 59.5 & N.D. & & 0.28 & 3.56 & 0.82 & & 120 & 2.5 \\
\hline 189 & 0.17 & -102 & 7.9 & 531 & 25.9 & 0.19 & 0.17 & 0.22 & 1.13 & 0.6 & 2.27 & 192 & 2.5 \\
\hline 190 & 0.17 & -126 & 7.85 & 316 & 2.88 & 0.04 & 0.03 & 0.16 & 0.36 & 0.62 & 3.53 & 252 & 2.5 \\
\hline 191 & 0.19 & -236 & 7.7 & 4566 & 291 & N.D. & & N.D. & 2.75 & 1.96 & & 42 & 48.5 \\
\hline
\end{tabular}

Sulfide $=\mathrm{H}_{2} \mathrm{~S}+\mathrm{HS}^{-}+\mathrm{S}^{-2}$.

Depth: below ground surface.

Distance: measured from the recharge area to the well site. 
Appendix 2 Values of $-\log (\mathrm{IAP})$ for some water samples.

\begin{tabular}{|c|c|c|c|c|c|c|}
\hline *NO. & $\mathrm{pH}$ & TDS mg/l & $* *$ Sulfide $\mathrm{mg} / \mathrm{l}$ & $\mathrm{HS}^{-} \mathrm{mg} / \mathrm{l}$ & $\mathrm{Fe}^{+2} \mathrm{mg} / \mathrm{l}$ & $-\log$ (IAP) \\
\hline 1 & 8.82 & 1372 & & 0.096 & 0.056 & 3.01 \\
\hline 2 & 8.86 & 1162 & & 0.048 & 0.039 & 3.41 \\
\hline 3 & 8.83 & 1204 & & 0.096 & 0.039 & 3.14 \\
\hline 4 & 8.82 & 1183 & & 0.192 & 0.039 & 2.85 \\
\hline 5 & 6.90 & 100 & 0.02 & 0.01 & 10.9 & 3.43 \\
\hline 6 & 7.80 & 100 & 0.06 & 0.05 & 0.350 & 3.32 \\
\hline 7 & 6.40 & 84 & 0.04 & 0.001 & 4.60 & 5.29 \\
\hline 8 & 8.00 & 147 & 0.01 & 0.009 & 0.80 & 3.52 \\
\hline 9 & 6.90 & 84 & 0.02 & 0.01 & 6.20 & 3.66 \\
\hline 10 & 8.20 & 63 & 0.06 & 0.05 & 0.100 & 3.44 \\
\hline 11 & 8.60 & 70 & 0.01 & 0.01 & 0.100 & 3.75 \\
\hline 12 & 8.40 & 77 & 0.12 & 0.11 & 0.100 & 2.91 \\
\hline 13 & 8.10 & 77 & 0.12 & 0.11 & 0.300 & 2.73 \\
\hline 14 & 5.60 & 300 & 0.06 & 0.003 & 0.179 & 7.09 \\
\hline 15 & 6.26 & 300 & 0.03 & 0.005 & 0.202 & 6.16 \\
\hline 16 & 6.00 & 100 & 0.20 & 0.02 & 15.0 & 3.88 \\
\hline 17 & 5.86 & 100 & 4.00 & 0.28 & 17.0 & 2.82 \\
\hline 18 & 5.99 & 100 & 0.86 & 0.08 & 9.00 & 3.51 \\
\hline 19 & 7.82 & 100 & 0.06 & 0.05 & 0.300 & 3.37 \\
\hline 20 & 6.60 & 100 & 0.80 & 0.22 & 16.4 & 2.20 \\
\hline 21 & 6.30 & 100 & 0.31 & 0.05 & 2.80 & 3.92 \\
\hline 22 & 6.21 & 100 & 0.20 & 0.03 & 8.00 & 3.77 \\
\hline 23 & 7.20 & 1600 & & 0.79 & 0.280 & 3.03 \\
\hline 24 & 7.30 & 4700 & & 3.42 & 0.227 & 2.54 \\
\hline 25 & 6.60 & 3200 & & 4.48 & 0.157 & 3.22 \\
\hline 26 & 7.00 & 3600 & & 5.86 & 0.123 & 2.83 \\
\hline 27 & 6.90 & 4100 & & 5.56 & 0.087 & 3.12 \\
\hline 28 & 6.30 & 32000 & & 5.68 & 0.087 & 4.05 \\
\hline 29 & 7.00 & 2100 & & 5.81 & 0.087 & 2.91 \\
\hline 30 & 7.10 & 1230 & & 2.31 & 0.157 & 2.89 \\
\hline 31 & 7.00 & 1800 & & 0.27 & 1.977 & 2.87 \\
\hline 32 & 7.00 & 2950 & & 3.64 & 0.105 & 3.08 \\
\hline 33 & 7.00 & 2200 & & 0.29 & 1.750 & 2.91 \\
\hline 34 & 6.90 & 1850 & & 3.35 & 0.157 & 2.98 \\
\hline 35 & 7.00 & 1790 & & 3.07 & 0.105 & 3.08 \\
\hline 36 & 7.00 & 1210 & & 1.77 & 0.053 & 3.58 \\
\hline 37 & 6.90 & 2320 & & 6.13 & 0.105 & 2.92 \\
\hline 38 & 6.80 & 2730 & & 5.81 & 0.123 & 2.99 \\
\hline 39 & 7.00 & 2710 & & 2.13 & 0.157 & 3.12 \\
\hline 40 & 7.10 & 3320 & & 0.13 & 3.640 & 2.90 \\
\hline 41 & 7.10 & 2310 & & 5.35 & 0.087 & 2.86 \\
\hline 42 & 7.10 & 2730 & & 5.11 & 0.105 & 2.82 \\
\hline 43 & 6.90 & 4450 & & 4.93 & 0.093 & 3.16 \\
\hline 44 & 6.90 & 6400 & & 4.42 & 0.079 & 3.33 \\
\hline 45 & 6.70 & 12300 & & 3.56 & 0.086 & 3.70 \\
\hline 46 & 7.71 & 260 & 0.39 & 0.32 & 0.007 & 4.35 \\
\hline 47 & 7.44 & 415 & 2.52 & 1.82 & 0.023 & 3.38 \\
\hline 48 & 7.78 & 235 & 1.05 & 0.90 & 0.025 & 3.27 \\
\hline 49 & 7.45 & 492 & 1.48 & 1.12 & 0.009 & 4.01 \\
\hline 50 & 7.45 & 683 & 1.92 & 1.42 & 0.019 & 3.61 \\
\hline 51 & 7.53 & 1068 & 2.29 & 1.74 & 0.053 & 3.04 \\
\hline 52 & 7.76 & 212 & 1.89 & 1.61 & 0.009 & 3.48 \\
\hline 53 & 7.73 & 235 & 0.46 & 0.39 & 0.089 & 3.14 \\
\hline 54 & 7.64 & 565 & 4.08 & 3.30 & 0.007 & 3.47 \\
\hline 55 & 8.16 & 658 & 3.47 & 3.26 & 0.016 & 2.61 \\
\hline 56 & 7.69 & 3511 & 6.02 & 5.00 & 0.105 & 2.27 \\
\hline 57 & 7.64 & 225 & 0.31 & 0.25 & 0.033 & 3.85 \\
\hline 58 & 7.71 & 310 & 1.16 & 0.96 & 0.124 & 2.64 \\
\hline 59 & 7.57 & 899 & 2.31 & 1.82 & 0.082 & 2.77 \\
\hline 60 & 7.68 & 1518 & 1.47 & 1.20 & 0.011 & 3.77 \\
\hline 61 & 7.55 & 1530 & 2.30 & 1.79 & 0.059 & 3.00 \\
\hline 62 & 7.43 & 1939 & 2.55 & 1.86 & 0.087 & 2.96 \\
\hline 63 & 7.73 & 601 & 4.08 & 3.43 & 0.019 & 2.93 \\
\hline 64 & 7.41 & 1656 & 2.77 & 1.99 & 0.123 & 2.78 \\
\hline 65 & 7.20 & 3061 & 5.30 & 3.23 & 0.403 & 2.35 \\
\hline
\end{tabular}

* data sources: NO. 1-4 from Thorstenson et al., 1979, NO. 5-6 from Champ et al., 1979 NO. 7-13 from Jackson and Patterson, 1982 , NO. 14-15
from Brown et al., 1999, NO. 16-22 from Macalady et al., 1990, NO. 23-45 from Zanini et al., 2000, NO. 46-65 from Plummer and Sprinkle, 2001. $* *$ sulfide $=\mathrm{H}_{2} \mathrm{~S}+\mathrm{HS}^{-}+\mathrm{S}^{-2}$ 